\title{
ABORIGINAL WOMEN AS PROVIDERS: THE 1830s ON THE SWAN
}

\author{
Sylvia J. Hallam
}

In The passing of the Aborigines Daisy Bates says of Fanny Balbuk, whom she considered to be 'the last [Aboriginal] Perth woman':

to the end of her life [in 1907] she raged and stormed at the usurping of her beloved home ground. One of her favourite annoyances was to stand at the gates of Government House, reviling all who dwelt within, because the stone gates guarded by a sentry enclosed her grandmother's burial ground ${ }^{1}$... Balbuk had been born on Huirison [Heirisson] Island ${ }^{2}$... and from there a straight track led to the place where once she had gathered jilgies ${ }^{3}$ and vegetable food with the women, in the swamp where Perth railway station now stands. Through fences and over them, Balbuk took the straight track to the end. When a house was built in the way, she broke its fence-palings with her digging stick and charged up the steps and through the rooms. ${ }^{4}$

Balbuk's irresistible progress against arbitrary European barriers took her from the fishing grounds in the river shallows on the south side of the east-west Perth ridge ${ }^{5}$ to the

Sylvia Hallam taught as Associate Professor in the Department of Archaeology at the University of Western Australia. Since 1989 she is Honorary Research Fellow in that Department.

1 Thus her claims to this locality were traced through the female line.

2 Heirisson Island separates the Swan River into two strands immediately east of the ridge on which Perth city centre was laid out. This west-east ridge commanded 'the flats', the shallows either side of Heirisson Island, the lowest crossing point on the river (except for the hazardous rocky bar at the mouth of the estuary in Fremantle) and was thus an important node in the Aboriginal communication and settlement systems. The ridge also commanded along its northern flank the subsistence resources of the line of lakes and swamps running east from Lake Monger through the low land north of the present railway to drain into the Swan along Claise Brook; and along its southern flank lay the rich fishing grounds in the shallows fringing Perth Water. Thus the Perth ridge was crucial to the Aboriginal group, 'Yalagonga's Tribe', whose holdings centred there. The ridge remained important in the British settlement pattern, and along its crest Sir James Stirling's surveyors laid out the four parallel streets which became the main arteries of the financial, administrative, commercial, shopping and communications centre of the city of Perth - St Georges Terrace, Murray Street, Hay Street and Wellington Street. These link eastward to form 'The Causeway', which crosses the Swan via Heirisson Island, at what used to be 'the flats'. Not only was this crossing important in the Aboriginal communications system, it has remained so in the European system, right up to the present, when it carries the Great Eastern Highway with traffic to the airport and to the eastern states.

For the continuing importance of Heirisson Island to Aboriginal people see Baines 1988: 233-242.

Jilgies are small freshwater crayfish.

4 Bates 1938:69-70.

5 See footnote 2. 


\section{ABORIGINAL WOMEN AS PROVIDERS}

lakes and swamps along the northern flank of the ridge, linking the major resource areas at the core of her group's terrain. The indomitable old lady, insisting on gathering predominantly plant foods from the resource patches where she and her mother and her mother's mother had held rights since time immemorial, can stand for all the generations of Aboriginal women who, before and after the coming of Europeans, had provided their families with the basic carbohydrate staples which comprised the bulk of their diet, and with the small protein supplements (jilgies, frogs, turtles, lizards), which together gave their families adequate nutrition, whether or not the men ever justified their fireside boasts of hunting prowess. Fish were another important element in the diet of the Swan Aborigines, and here both men and women combined to gather an abundant harvest. ${ }^{6}$

Fanny Balbuk was probably born about $1840 .^{7}$ The pattern of individual localised rights to the produce of particular swamps, the produce of particular patches of ground, which Bates records for Balbuk, must be seen as the norm, which had survived intact through and beyond the first decade of European intrusion. The claim persisted into the present century, despite the colonists' efforts to eliminate such inconvenience, even here at the heart of the Swan River Settlement.

The Europeans assumed that the land of the Swan River Settlement was 'terra nullius', literally 'land of nobody', 8 that is, in the words of a Privy Council decision of $1889^{9}$ a tract of territory practically unoccupied, without settled inhabitants or law. 10 The legal concept implied that folk in such a territory were not 'settled', in the sense of holding rights and responsibilities in specific localities, but rather wandered at random, picking up what they could where they could. This was very far from the truth for the Swan River Settlement. On the contrary, despite the immense omissions and misunderstandings which bedevil the contemporary documents from the pen of the Europeans, we can build up a picture, fragmentary and disjointed though it may be, of the complex system of rights and responsibilities which tied Aboriginal families to the land of their mothers and their mothers' mothers, their wives and their wives' mothers, and gave them access also to the land of their mother's husband, their husbands' mother or their fathers' mother and even to the land of a brother's wife. This closely regulated yet flexible system constituted a body of Aboriginal law, linked to a corresponding body of lore, the birthright of generations of Aboriginal women and their menfolk and the body of knowledge and skills involved in maintaining and managing, improving and harvesting, both ritually and ecologically, the resources of an area.

Occasionally rights in land might be granted to outsiders, to the mutual advantage of both groups, particularly if a kin relationship could be traced. Sometimes Aboriginal groups attempted to negotiate such arrangements with European settlers, ${ }^{11}$ although the settlers

6 Hallam 1987b:25-27.

7 Hallam and Tilbrook 1990:112-3.

8 Or 'res nullius', 'the legal equivalent of a desert island' (Hookey 1984:1-2). The whole paper provides a brief discussion of the legal assumptions behind the claim that Britain acquired sovereignty over all Australia by settling, in 1788, land previously not settled, where no tenure of any sort existed. See also discussion of the meaning of 'terra nullius' 'land belonging to no-one', in Reynolds 1987:12-14.

9 Reynolds 1988:17-18. This brief paper discusses, with full legal references, the extraordinary disregard and dismissal of Aboriginal rights in land by European historians and lawyers. See also Reynolds 1987, cited in footnote 8 above.

10 My emphasis, S.J.H.

11 Hallam 1983. 


\section{ABORIGINAL HISTORY 1991 15:1}

rarely appreciated the formal and binding nature of such 'treaty' negotiations. Often the Aborigines claimed the Europeans as their dead ancestors retumed, as did Sir George Grey's Aboriginal 'mother'; 12 and this assumption explains why they initially allowed, or did not actively oppose, white intrusion on their land holdings. As Grey explains, the original Australians themselves:

never having an idea of quitting their own land, cannot imagine others doing it; - and thus when they see white people suddenly appear in their country, and settling themselves down in particular spots, they imagine they must have formed an attachment to this land in some other state of existence; and hence conclude the settlers were at one period black men, and their own relations. ${ }^{13}$

Aborigines soon realised that their respect for the body of lore and law relating to land use was not shared by the intruders, and found themselves excluded from localities in which they held, under Aboriginal law, rights vital to the integrated patterns of Aboriginal subsistence and society.

Our knowledge of the crucial role of women as holders and managers of land and its resources, and the importance of plant staples in the Aboriginal economy, has to be pieced together largely from British accounts, with some support from patterns of archaeological distributions relative to plant distributions. ${ }^{14}$ But these records are often defective. They are frequently most concerned with the clashes which occurred as a result of the settlers' ignorance of Aboriginal law, and they assume the absolute validity of their own very different system of land holding. Consequently we get a warped view, in which men and their doings are seen as all-important, and women largely ignored. Land holding is interpreted in the patrilineal terms of the British legal system. However an examination of the composition of groups recorded in various areas shows that the groupings cannot be explained on patrilineal assumptions, and the links and continuity lie through the women rather than the men. ${ }^{15}$ The importance of plants in Aboriginal subsistence patterns, and of women as plant-managers and harvesters, also becomes very clear in the writings of botanically knowledgable observers.

The West Australian evidence should come as no surprise, for the continent of Australia was peopled from the tropics, and tropical subsistence systems, whether we label them agricultural, horticultural, or hunter-gatherer, are on a world scale predominantly plantbased, and have been so as far back as the archaeological evidence can be traced. Archaeologists and ethnographers have become increasingly aware over the last few years of the importance of plant staples to subsistence patterns and consequently to settlement patterns, for plants occur in fixed patches which bring people back to the same locality year after year, often for long periods. ${ }^{16}$

I shall examine a number of examples, mainly from the first decade of European occupation of the core of the Swan River Settlement, which became the city centre of Perth itself and its immediate environs, showing the importance of fixed plant resources to

12 Hallam 1983:138-140.

13 Grey 1841:I:302-3; Hallam 1983.

14 See Hallam 1987a.

15 Compare Tilbrook 1986; Birdsall 1988.

16 Meagher 1974; Hallam 1975; Meagher and Ride 1979; Meehan 1982; Gott 1984; Hallam 1986, 1989; Beck, Clarke and Head 1989. 


\section{ABORIGINAL WOMEN AS PROVIDERS}

Aboriginal subsistence, the role of women as providers, and the effects of European disruption. 17

\section{People on the lower Swan}

Coming up the Swan estuary from the sea in the 1830 s, we would first encounter north of the river the foraging group made up of the elderly and much respected Yellowgonga, his wives Yangan and Windan, and his daughters and their husbands. These individuals appear again and again in various incidents along the north side of the Swan estuary from Freshwater Bay to the ford at the present Causeway just east of the city centre of Perth, and from the banks of the river by Kings Park to the lakes now called Herdsmans and Mongers Lakes. ${ }^{18}$

Fanny Balbuk's ties to land lay in this area. Bates gives Yalgonga (Yellowgonga), as Fanny Balbuk's grandfather. The grandmother buried in the grounds of Government House was probably one of his wives. Bates tells us that Yalgonga's favourite kala or hearth lay 'by the spring on the Mounts Bay side of Kings Park', that is somewhere along the line of springs which stretched from the old Swan Brewery to the Emu Brewery, Spring Street and beyond, at the foot of the slope, from the Perth city ridge to the river. ${ }^{19}$ Before European intrusion this group had commanded the ridge which is now the city block, between the shallows of Perth Water. with their abundance of fish, to the south, and the lakes and swamps from Lake Monger across to Claise Brook, to the north. Robert Menli Lyon ${ }^{20}$ in 1833 translated the name Byerbrup as:

the highland stretching from Mount Eliza, through the centre of the town of Perth. The camp of Yellowgonga bearing this name originally stood beside the spring at the West end of the town as you descend from Mount Eliza, and on this spot did the 63rd [regiment] pitch their tents when they came to take possession...

This implies a camp at the top of St George's Terrace, embracing the area from the Barracks right in front of Parliament House, down the slope below to the springs of Spring Street and the Bishop's house. Well may Lyon add:

the headquarters of the king of Mooro are now become the headquarters of the territories of the British king in Western Australia. Sic transit gloria mundi $\ldots 21$

However, the focal area must have extended not only down the southern slope towards the river, but eastward along the Perth ridge towards the river crossing at 'the flats' (the Causeway), for Lyon adds:

17 This is a slightly amended version of a paper first delivered to the Centre for Western Australian History Conference held at the University of Western Australia at Nedlands, in April 1991. The evidence was readily available to me because of the joint work I had undertaken over a number of years with Lois Tilbrook on one of the Aboriginal volumes in the Bicentennial Dictionary of Western Australiaris (Hallam and Tilbrook 1990). I owe an immense debt of gratitude to Lois for turning my interests from purely archaeological to ethnohistorical matters, in the direction of Aboriginal lives as well as livelihood.

' 8 Hállam and Tilbrook 1990:348:354. References to sources will be found in this volume.

19 Ibid.:112-3.

20 Lyon 1833.

21 Ibid. 
The position was very important to Yellowgonga. It was not only convenient for hunting and fishing, but it gave him the command of the flats ... the river being hardly fordable anywhere else. 22

Elsewhere Lyon described the wider district over which members of Yellowgonga's group held rights of usufruct as:

bounded by the sea on the west; by Melville Water and the Swan on the south; by Ellen's Brook on the east; and by Gyngoorda [the Moore River] on the north

and Armstrong in 1836 said that Yalagonga and his sons, Nandaree and Elal:

claim all land between Mount Eliza and Fremantle and from the river towards Mr Trigg's lime kiln [Trigg Island?]. ${ }^{23}$

Both these claims must represent the furthest range of group members, rather than the core of their estates. And both state ownership in European, patrilineal, terms, rather than emphasising the matrilineal groupings, ${ }^{24}$ as we shall see, which provided the continuity in group membership and land holding.

Grey in 1838 lists Yellowgonga himself as a 'Didaroke' a member of a group centred on the hills east of the coastal plain. ${ }^{25}$ His rights to the land immediately north of the Swan were presumably held through one or both of his wives, Yangan and Windan. Windan was shown as belonging to the Ballaroke classificatory group in the list of Swan River Aborigines drawn up by George Grey in 1838.26 Other members of the Ballaroke descent group, which would include her offspring, and also her mother and her mother's offspring, would have similar rights. ${ }^{27}$ Possibly Yellowgonga may also have held claims through his other wife, Yangan, about whom less information survives. All Yellowgonga's children whose grouping is recorded belong to the Ballarokes, the same matrilineal descent group as Windan, so presumably her co-wife was also a Ballaroke, and perhaps Windan's sister. It was not infrequent for a man to marry two sisters, for instance two of Yellowgonga's daughters 28 married the same man.

The family were frequent visitors to the Native Institution at the foot of Mount Eliza, near the heart of their estate. They also frequented the surrounds of Mongers Lake. Lyon stated in 1833:

To this place Yellowgonga removed his headquarters, after the formation of the settlement.

European dominance had quickly forced Aboriginal groups away from their economically and socially strategic position on the city ridge overlooking the lowest ford on the Swan. Instead they frequented their marginal camps around that ridge - at the foot of Kings Park,

22 Ibid.

23 Lyon 1833 and Armstrong. 1836.

24 Compare Birdsall 1988:139, 143.

25 Grey 1838.

26 Ibid.

27 For the matrilineal nature of 'family' names ('totemic clans') in southwest Australia see Berndt 1979:82-3. See also the genealogies on the endpapers of the Bicentennial dictionary of Aborigines of the southwest region. These are based on information in the genealogies in Grey 1841:II:391-4; supplemented by Grey 1838, and Armstrong 1837 and other censuses (Hallam and Tilbrook 1990).

28. We do not know whether Gargup and Daleer had the same mother as well as the same father. Armstrong's 1837 census lists wives with their husband, followed by all his offspring. without stating which offspring belonged to which wife. 


\section{ABORIGINAL WOMEN AS PROVIDERS}

at Heirisson Island, in East Perth near the Claise Brook, and by the chain of lakes westward to Hyde Park Lake and Lake Monger, completing the circle through the Shenton Park Lake and Crawley/Pelican Point areas, the present site of the University of Western Australia. Either archaeological or ethnographic evidence or both is known from each of these localities.

Yellowgonga almost certainly had access to his Lake Monger retreat through his wife, Yangan, and shared those access rights with other offspring of Yangan's mother, and their spouses and offspring. Thus Yangan's brother, Boogaberry, was listed by Francis Armstrong in 1836 as a co-owner of the chain of lakes east from Mongers Lake and north of Perth city, including Fanny Balbuk's jilgie and reed rhizome harvesting swamp where Perth Railway Station now lies. 29

In 1836 William Leeder's son became embroiled in a dispute with Boogaberry because Aborigines had been digging potatoes on the land by Lake Monger which Leeder then held under a British grant. Boogaberry's sister (presumably maternal), Yangan, was described as 'a notorious thief, no doubt because she insisted on exercising her family's rights to harvest the reed rhizomes and other tubers of this area, grinding them to provide a starchy flour for 'dampers'. Her brother defended those rights. Later Yangan was also accused of taking potatoes from Mr Shenton's land, possibly that on which the University now stands, again the exercise of the rights of her matrilineal group. ${ }^{30}$

The pattern of men holding rights through women was repeated in the next generation. Yellowgonga and his wives had at least four sons and three daughters. Our British informants, thinking in patrilineal terms, do not tell us which wife was mother to which of the offspring, but all those whose matrilineal kin classification is listed are Ballarokes like Windan. Two of the daughters, Gargup and Daleer, both married Ningana, whose father is stated to be from the Murray, the next river southward from the Swan. The two sisters frequented the ration depot set up at the foot of Mount Eliza, with their husband, his two brothers and a brother's wife; and with their other sisters, one or other of their own brothers, and their father, their mother, and her co-wife. The husband, Ningana, was certainly not hunting and foraging on the land of his father and his father's kin, but on that of his wives and their mother, and mother's brother.

On one occasion in February 1835 the activities of the family group at the Native Institution at the foot of the King's Park cliff were recorded in some detail. Gargup and her infant, and her sister Daleer, were accompanied by their brother Nander, their (joint) husband, Ningana, plus Ningana's brothers Dommera and Edar, and some others about whose kinship we know nothing. They were said to be hunting wallabies, fishing, and 'burying zamia nuts'. 31 The last implies processing to detoxify the zamia fruit (as for their close relatives, the cycads), and simultaneously storing the product for future use, perhaps to provide sustenance for a ceremonial gathering. ${ }^{32}$

Much the same group had been together on the shores of Freshwater Bay in February 1834, when as many as 160 men, women and children were gathered around Perth and the lower Swan. John Butler complained that the group molested his goats. Probably the seasonal aggregation brought considerable pressures on resources which would have been sufficient had they not been disrupted by white presence. ${ }^{33}$

Hallam and Tilbrook 1990:28-9.

Ibid.:343.

31 CSR 37/231.

32 See below.

33 Hallam and Tilbrook 1990:55-6. 


\section{ABORIGINAL HISTORY $1991 \quad 15: 1$}

It is interesting that the three brothers joined the wife of one of them in exploiting the resources of the women's land. Marriage relationships must be seen as giving many individuals the option of access to the domains of their in-laws, and obviously only a few of those options could ever be taken up for long periods. Potential rights became actual rights only if they were maintained by use.

\section{Subsistence on the lower Swan}

On the lower reaches of the Swan plant resources were probably less important than further up the river, but even here the women could muster sufficient storable carbohydrate staples to help support relatively large groups for at least a short period. Zamia nuts are a particularly interesting resource, implying considerable knowledge and skill to enable them to be utilised. The nuts contain a toxin which must be leached out before they can be safely eaten, as various European visitors have found to their cost. In June 1801 an exploring party from the French vessel Naturaliste, penetrating twelve miles inland along the Swan, had found two Aboriginal huts, spears, fish, and a cache of zamia nuts, which they roasted and ate, becoming severely ill as a result. ${ }^{34}$ Vlamingh's men had the same experience over a hundred years earlier. ${ }^{35}$ The important technology of detoxification, by leaching in water or simply caching in a pit for a sufficient period to allow breakdown of the toxins, was probably brought to the continent by its first settlers. Certainly it is already attested in the southwest of Australia in the archaeological record for the late Pleistocene, some 13000 years ago. ${ }^{36}$ The women could prepare ahead for ceremonial gatherings by soaking the zamia fruits for several days in water, and caching them in pits to complete the detoxification. The pulp could then be eaten raw or roasted, when it tasted like chestnuts. ${ }^{37}$

'Hunting wallabies' near the Native Institution might be seen as a totally male activity, but even in this the women had their role. Daisy Bates gives an account of a kangaroo drive, still occurring early this century, in a valley leading down to a steep drop over the Kings Park cliff. This must have taken place in the hollow where the Pioneer women's fountain is now placed, leading down to a sheer drop to the old Swan Brewery on the site of the 1830 s Native Institution below:

What is now King's Park, Perth, was once a favourite place for a battue, the slopes of the park towards Crawley and Subiaco furnishing good herbage at certain seasons. The natives engaged in the hunt assembled at a certain point and from there each man took up his position at some spot ... At a given signal some bushes in the vicinity were fired, one outlet only being left for the kangaroo, that outlet being an almost perpendicular descent in the vicinity of Mounts Bay. The maddened animals, helped by shrieks, yells, smoke and flames, rushed headlong towards the foot of the Mount. There, at various points several natives were stationed with their heavy hunting spears in readiness, and the tumbling and floundering animals were quickly and easily despatched.

Women and children may take part in these batlues, provided sufficient cover is available.

34 Marchant 1982:169; cf. Milius in Bonnemains and Haugel 1987; Peron 1809:146.

35 Robert 1972:66-77.

36 Smith 1982.

37 Grey 1841:II:295-7. 


\section{ABORIGINAL WOMEN AS PROVIDERS}

Much feasting and gorging took place after a successful drive. The women made cloaks and bags of the female ${ }^{38}$ kangaroo skins. ${ }^{39}$

Such drives would only be possible, or necessary, when there were large gatherings of people for ceremonial occasions, and this account does suggest that aggregations such as that in February 1834 might have been based on the Kennedy Fountain /Swan Brewery area once the water sources and camping spots nearer the city centre ceased to be available. Indeed it was at the foot of this cliff that zamia caches, suitable for supporting large aggregations, were recorded not only in the 1830 s, but also thirty years earlier, and possibly two hundred years before that. 40

Aborigines, however, continued to frequent the river fringe of the city right through the nineteenth century, and into the early years of this century, fishing in the shallow waters at the foot of the Perth ridge. Jesse Hammond, bom in 1856, reported that in the 1860 s natives used to spear cobblers in the shallow waters between the Barrack Street and the William Street jetties, and in the shallows at the ford by Heirisson Islands; ${ }^{41}$ while James Kennedy, born in 1848, recalled from his boyhood 'natives in dozens' spearing cobbles in the shallow waters below St George's Terrace and the Esplanade. ${ }^{42}$

Shoals of small fish were most plentiful in the shallows of the Swan towards autumn, when zamia nuts also became available, so in that season large groups of people were able to assemble for firing the countryside and for ceremonial and social gatherings. Moore's Vocabulary gives:

Burnur or Burnuro - The autumn of Western Australia, including the months of February and March. This is the $B y-y u$ or Zamia-fruit season; and mullet, salmon and tailor-fish abound. 43

The surveyor, Phillip Snell Chauncy, in the 1840s watched Aborigines at Swan River: drive a shoal of large schnappers into water too shallow for them to swim in, and spear and catch a great number of fish weighing from ten to fifteen pounds each.

The women would help in driving the fish into the shallows, as in Chauncy's report of catching fish at King George Sound, where:

Two or three women watch the shoal from the beach, keeping opposite to it, while twenty or thirty men and women take boughs and form a semi-circle out in the shallow bay ... then closing gradually in, they hedge the fish up in a small space close to the shore, while a few others go in and throw them out with their hands.

By such methods he had seen large quantities of fish caught, as in the Swan River example. 44

Women also participated in driving shoals of small fish into the corners of tidal weirs as the tide filtered out, where again they could be scooped up by hand. 45 Prodigious quantities of fish could be taken at fish weirs, either riverine structures like the stone weir

\footnotetext{
38 I am intrigued to know why the skins had to be female!

39 Bates 1985:244-5.

40 See notes $31,34,35$.

41 Hammond 1933:19; Hammond 1936:185.

42 Kennedy 1927:7-10.

43 Moore 1884: Vocabulary:16.

44 Chauncy 1878:248-9.

45 Bunbury and Morrell 1930:87.
} 


\section{ABORIGINAL HISTORY $1991 \quad 15: 1$}

on the Kalgan River, or the elaborate brushwood barrier which survived on the SerpentineMurray estuary well into this century; or tidal weirs like those whose remains survive in Oyster Harbour at King George Sound ${ }^{46}$ and reportedly until recently on the south side of the Swan estuary. At such weirs,

fish have been found left in heaps by the natives after they had used what they needed. 47

Fish might be cooked simply by broiling on the fire or with more finesse:

A piece of thick and tender paper bark is selected, and torn into an oblong form; the fish is laid in this, and the bark wrapt around it, as paper is folded round a cutlet; strings formed of grass are then wound tightly about the bark and fish, which is then slowly baked in heated sand, covered with hot ashes; when it is completed the bark is opened, and serves as a dish: it is of course full of juice and gravy, not a drop of which has escaped. 48

\section{Lakes and swamps - small game and plantstaples}

As well as their role in fishing, game-drives, and zamia processing women on the lower Swan would be able to harvest small game and lake and swamp products, as Balbuk prized her jilgies and vegetable foods. Lizards were most abundant in December and January. Freshwater tortoises were most easily captured when lakes like those north of Perth had shrunk to their minimum. George Grey tells us how they were cooked:

These fresh water turtle are cooked by being baked, shell and all, in the hot ashes; when they are done, a single pull removes the bottom shell, and the whole animal remains in the upper one, which serves as a dish. They are generally very fat, and are really delicate and delicious eating. 49 tells us:

Even more abundant in lakes and swamps were frogs and freshwater crustaceans. Grey

The season of the year in which the natives catch the greatest quantity of frogs, and freshwater shellfish, ${ }^{50}$ is when the swamps are nearly dried up; these animals then bury themselves in holes in the mud, and the native women with their long sticks, and their long thin arms, which they plunge up to the shoulder in the slime, manage to drag them out; at all seasons however they catch some of these animals, but in summer a whole troop of native women may be seen paddling about in a swamp, slapping themselves to kill the mosquitoes and sandflies, and every now and then plunging their arms down into the mud and dragging forth their prey. I have often seen them with ten or twelve pounds weight of frogs in their bag.

Frogs are cooked on a slow fire of wood ashes, they are then held in one hand by the hind legs, and a dexterous pinch with the finger and thumb of the other, at once removes the lower portion of the intestines, the remainder of the animal is then taken at a mouthful and fairly eaten from the head to the toes. 51

\section{Gibb 1987.}

Irwin 1835:23.

48 Grey 1841:11:276.

49 Ibid.:280.

50 Grey intends crustaceans, not molluscs.

51 Grey 1841:11:287-8. 


\section{ABORIGINAL WOMEN AS PROVIDERS}

These delicacies were still available at the very end of the dry season, in April before the first rains. When Sir George Grey, weak with hunger after a trek down the coast from his shipwrecked vessel at the mouth of the Murchison, reached Lake Joondalup it was the women who provided for him from the abundance which they could harvest from the coastal swamps and lakes at the time of year which seems most difficult to Europeans:

The women were soon called up, bark baskets of frogs opened for us, by-yu nuts

roasted, and as a special delicacy I obtained a small fresh-water tortoise. ${ }^{52}$

Later his Aboriginal friend, Imbat, upbraided Grey - 'where is your fat?' and then:

forgetting his anger, burst into a roar of laughter, and saying 'and 1 know how

to make you fat,' - began stuffing me with frogs, barde [grubs] and by-yu [zamia] nuts. 53

Where the Europeans had starved the Aboriginal women could provide abundant and reliable fare.

All these resources would be available in the swamps and lakes around the earliest British settlement on the Swan - those on the northern side of the Perth ridge, and others like Lake Monger, Herdsmans Lake, Shenton Park Lake or Butlers Swamp (Lake Claremont). The most important and reliable resources these wetlands had to offer, however, were plant foods, and carbohydrate staples, particularly reed rhizomes. James Backhouse, visiting Perth in 1836 wrote of

some lagoons at the back of the town ... The lagoons are much filled with

Cats-tail Reed, Typha latifolia, the root of which is eaten by the natives. 54

Grey has a detailed account of the use of reed rhizomes (though there are some difficulties about precise species identification):

yun-jid ... is the root of a species of flag, and consists of a case enclosing a

multitude of tender filaments, with nodules of farinaceous matter adhering to

them. These are collected into a mass by pounding the root and the cake

formed from the mass is very nice.

Aboriginal women were thus the first Australians to make damper! Interestingly Grey added:

The natives must be admitted to bestow a sort of cultivation upon this root, as they frequently burn the leaves of the plant in the dry seasons, in order to improve it. 55

George Fletcher Moore gives a similar account of the use of reeds as a source of dietary starch, transcribing the Aboriginal word as:

Yanjidi - An edible root of a species of flag (Typha angustifolia) growing along freshwater streams and the banks of pools. It consists of many tender filaments with layers of a farinaceous substance between. The natives dig the roots up, clean them, roast them, and pound them into a mass, which when kneaded and made into a cake, tastes like flour not separated from the bran. 56

The botanist James Drummond also made clear the importance of plant carbohydrate and particularly swamp products in the Aboriginal diet. He was guided across the hills to the Avon valley, at the point where what is now the Toodyay Brook joins the river. This place

\footnotetext{
52 Ibid.:91-2.

53 Ibid.:93.

54 Backhouse 1843:531.

55 Grey 1841:II:294.

56 Moore 1884: Vocabulary: 81.
} 
took its name from the plant resources which enabled families to focus on the area for months at a time:

I leamt from Babbing this place is called Duidgee and that it is a favourite haunt of the natives ... The reedmace ... grows in abundance in the bed of the stream. This plant is one of great importance to the natives, as furnishing a great part of the food of their women and children for several months of the year ... the roots ... are thick and succulent, contain a large portion of starch and mucilage ... generally abounds near water. ${ }^{57}$

\section{Staples and stability}

Where more than one staple, with different harvesting periods, occurred in the same area, women were able to support their families for much of the year in the same general locality, forming a stable focal area about which the men, particularly the young men, could range far afield for hunting, social and ritual purposes. Examples of such multi-staple localities include - Duidgee itself, with yam tubers as well as reeds; the Perth ridge, with swamp products and fish; Walyunga, with zamias and swamp products; and the upper Swan area with sidechannel swamps alongside the river, and yams on the alluvium of the river terraces.

I shall not discuss here those numerous other plant resources which form useful minor supplements to the diet rather than major staples like reedswamps in the sandplain or yampatches on the alluvium. Most of the lesser sources of plant carbohydrates (such as orchids and several species of Haemodorum ${ }^{58}$ ) occur in a more scattered fashion and not in patches sufficiently concentrated to attract foci of settlement.

Yams, however, were very important to Aboriginal subsistence and settlement patterns because they occurred in concentrated localised patches, mainly on rich alluvial soils. Indeed the European settlers used them as an indicator of good arable land, with devastating consequences for their Aboriginal owners. Where European settlers took over fertile yam-growing soils there is a chance for the survival of evidence about fluctuations in the numbers of Aborigines frequenting those areas, and the seasonality, periodicity and lengths of time involved. Obviously, however, the pre-European situation will almost immediately be altered by the effects of European cultivation and stock, and the assertion of European property rights. For the alluvial soils in the area around the new town of Perth itself the evidence is unclear, but further upstream grants of land on either side of the river where it runs southward down the coastal plain, were taken up by individual settlers, including men of education and intellect, who proved more discriminating and sympathetic recorders. Among them was George Fletcher Moore, Advocate-General, farmer, geologist, botanist, zoologist, anthropologist, linguist, lexicographer and diarist, recording everything which excited his universal interest. 59

At upper Swan the Swan/Avon River emerges from the scarp westward onto the coastal plain, depositing the rich alluvium which spelt fertility to Stirling and his men, as it had to thousands of generations of Aboriginal plant-harvesters before them. The area offered as staples not only the starchy reed rhizomes from the side channels of the river (supplemented

57 Drummond 1836.

58 Grey 1841:II:291-4; Meagher 1974; Meagher and Ride 1979.

59 See Tom Stannage's introduction to the 1978 University of Western Australia Press facsimile edition of George Fletcher Moore's Diary for the years 1830 to 1840 , first published in book form in 1884, along with a reprint of his 1842 Vocabulary (Moore 1884). 


\section{ABORIGINAL WOMEN AS PROVIDERS}

by frogs, crayfish, turtles, fish, birdlife, and game attracted by the water); but also extensive patches of the yam, Dioscorea hastifolia, so welldefined and fixed that they are marked on the earliest European maps of the area. George Fletcher Moore held a grant at 'Millendon', less than a kilometre south of the westward-flowing stretch of the Swan where it emerges from the Darling Scarp, and east of the southward course it then takes. Phillip Snell Chauncy's maps of 1843 show 'warran holes' (yam-digging pits) in a 'dogwood thicket' over two patches of ground along the northern boundary of the east-west strip granted to Moore's northern neighbour, William Shaw, extending onto the property of Peter Broun immediately south of the Swan (now Bond's 'Brigadoon' property); and another patch west of the river, on Lieutenant Irwin's property opposite Moore's. Stirling's botanist, Charles Fraser, in 1827 had observed the river bank hereabouts 'perforated by immense numbers of deep pits'. 60

On these high alluvial terraces, maintained by Aboriginal burning as the parklike 'open level country thinly wooded with red gums', shown on Chauncy's maps, these 'thickets' with their yam-vines stand out as areas deliberately protected from fire. James Backhouse, the Quaker evangelist, visiting Moore in 1836:

went with him to see a little of the country... A considerable number of blacks were assembled on one farm ... We examined some holes where the Natives had been digging for the roots of a Dioscorea, or yam, for food. This plant climbs among bushes [the 'dogwood thicket'] in a strongish soil, and the natives have a tradition, respecting its roots having been conferred upon them, in which there are traces of the deluge. ${ }^{61}$

Moore himself is explicit about the important role of yams in the Aboriginal diet: Warran - one of the Dioscoreae. A species of yam, the root of which grows generally to about the thickness of a man's thumb; and to the depth of sometimes four to six feet in loamy soils. It is sought chiefly at the commencement of the rains [that is April or May], when it is most easily dug; and it forms the principle article of food of the natives at that season. ${ }^{62}$

The surveyor Chauncy estimated the size of warran tubers, and the labour of digging them, as even greater:

I have seen both men and women sinking in loose sandy soil for an edible root called warran, which generally grows about the thickness of a man's thumb, and to the depth of four to six or eight feet. It has a sweet and delicate flavour when roasted in the hot ashes and is much sought after. It is dangerous to ride on horseback through the country where it grows, on account of the frequency and depth of the holes, which are not more than about eighteen or twenty inches in diameter. 63

The depth given is consistent with warran holes which have silted up, but are still three to five feet deep, which I have seen in the Gingin area. Lieutenant Breton fell shoulderdeep into one of a group of holes which he took to be pit-traps in riding up the Canning in 1829 , and Fraser in 1827 probably mistook warran holes for pit-traps.

Grey's more modest estimate of the size of most yams agrees more closely with my own limited experiments, but he is even more explicit about the labour involved:

60 Hallam 1975:14,58; 1986; 1989.

61 Backhouse 1843:538-540.

62 Moore 1884:Vocabulary:74.

63 Chauncy 1878:245-6. 
It is generally considered the province of the women to dig roots, and for this purpose they carry a long pointed stick, which is held in the right hand, and driven firmly into the ground, where it is shaken, so as to loosen the earth, which is scooped up and thrown out with the fingers of the left hand, and in this manner they dig with great rapidity. But the labour in proportion to the amount obtained is great. To get a yam about half an inch in circumference the must mean diameter] and a foot in length [about the size of those I have dug] they have to dig a hole about a foot square and two feet in depth; a considerable portion of the time of the women and children is therefore passed in this employment.

Obviously a yam ground is a fixed resource patch which ties the women and their families to a particular neighbourhood at certain seasons, though the young and mature men were much more mobile about these focal areas.

If the men are absent upon any expedition, the females are left in charge of one who is old or sick; and in traversing the bush you often stumble on a large party of them, scattered about in the forest, digging roots and collecting the different species of fungus. ${ }^{64}$

Moore's Diary shows that, despite European presence, Aboriginal families tried to maintain their pattern of continuing use of the upper Swan valley over much of the year. In June 1833 Moore was approached by Beelycoomera (Bilumera), son of Weeip (one of the many sons of Helia, a revered patriarch of the local group), and a group of ten Aborigines, including 'two well-looking young women with children at their backs'. He let Moore know by signs that the group wished to dig tubers, which they did despite Moore's disquiet because his sheep were pastured in the area. The problem would be soon solved for Moore, for the sheep would inevitably eat out the above-ground vines of the yams. Among Moore's visitors was Doodyeep or Toodyeep, a pretty coquettish girl, 'celebrated as the fairest of the fair', whose marriage to the youthful and vigorous Coondebung had just been celebrated in a great corrobory, ${ }^{65}$ no doubt made possible by the combinations of reeds, yams and zamias in the vicinity.

In February 1834 Moore reported 'numbers of natives here today'. In March Moore described himself as 'beset by natives' with 'a lot of native boys and girls' splashing merrily in the river. A fortnight later their elders steeped redgum blossoms in water to make festive drinks, perhaps somewhat fermented:

This day I have had a number of natives here. Some of them were busy sucking the honey water which they extracted from the flowers of the red gum tree; others baking their flour into cakes.

At this time of year the flour could be either from reeds or from yams, both available nearby. ${ }^{66}$ In May the group were:

busy digging the root of a broad sort of flag which grows in a swamp near this and a few days later he

got from the natives a piece of bread made of the root of a flag which they call

yandyelt. It tastes like a cake of oatmeal.

Large groups remained ensconced in the neighbourhood through June and into July; around twenty men visited Moore, implying fifty or more people camped nearby. By October

64 Grey 1841:II:292-3.

65 Moore 1884: Diary: 198.

66 Ibid.:212-5. 


\section{ABORIGINAL WOMEN AS PROVIDERS}

(when a new crop of yams could be obtained before the ground hardened) 'great numbers' were around again, including strangers from other areas. 67

Moore summoned military assistance on the $23 \mathrm{rd}$, and two days later reported that:

The natives have all dispersed today ... they did not like the appearance of the

police and soldiers visiting them.

His friend Tomchin said they would be gone for four months - that is they would return for the next reed and yam harvests in the late summer to early autumn. But it seems that the core of the local group remained on the coastal plain alluvium, for ten days later Moore reported that native 'women had been stealing Mr Shaw's potatoes.' (that is, digging tubers in the area where they were accustomed to dig tubers). At the rumour that the soldiers were in pursuit (this was only a day or two after the massacre at Pinjarra) the Aborigines 'ran from their fires, thinking the soldiers were in pursuit of them' and later called on Moore for advice on what was to be done. 68

This episode sums up within itself all the paradoxes of the situation. The women who hold rights in this land are prevented from harvesting major staples because their land is in the hands of white grantees, and they are harrassed by soldiers and police. When the women do harvest tubers on the land where they have entitlement, they are seen as thieves under British law, as though they and not the newcomers were intruding. And Moore, as representative of British law, though he remains on good terms with the Aborigines, showed no inkling that the rights granted by the British crown clashed with rights held in this locality by thousands of generations of Aborigines. On the same twenty metre terrace on the opposite side of the river is the upper Swan archaeological site, where Aboriginal artefacts lie in alluvial deposits around 40,000 years old. ${ }^{69}$

Doodyeep and Coondebung initially maintained friendly relations with Moore. Indeed, in May 1836 they escorted him northward and introduced him to people in the Chittering valley, rich in swamp resources and wildfowl. On the ridge between the scarp and the valley Coondebung's whole demeanour changed, he walked tall and with a springy step, because:

they were now passing through his own country, over his native soil.

Moore describes his agility, hunting prowess, and zest for life. That evening he ate -

a bandicoot, an opossum, two kangaroo-rats, a young swan and a musk duck

plus a damper; while Moore describes Doodyeep's share as 'not a Benjamin's portion.' But by the next summer Aboriginal access to upper Swan resources had been so restricted that they turned to Europeans as the remaining resource. Coondebung took wheat from Moore's property and a warrant was issued for his arrest. He took refuge in the bush (perhaps Walyunga or the Chittering valley) and in July 1839 he was reported to be sending his wife and child

into the settlements ... He desired her to say that he could not feed her, as he was afraid to hunt whilst the white people were unfriendly. They now feel the want of bread as a privation. 70

The story does not have a happy ending. Coondebung was captured and sentenced in April 1840 to seven years transportation to Rottnest Island, where he died of malnutrition in October. 71

67

68

Ibid.:231-4.

lbid.:235-8

69 Pearce and Barbetti 1981.

70 Moore 1884: Diary:387.

71 Hallam and Tilbrook 1990:48-51, 83-5. 
Moore does not seem to have realised that the need for flour and bread resulted less from declining opportunities for men to hunt than from a decade in which European fences, sheep crops, and guns had deprived Aboriginal women of access to the land to which they held rights and the carbohydrate staples they used to harvest there. The women were still expected to be the providers, but within a decade the Europeans had become the resource from which they had to harvest.

\section{BIBLIOGRAPHY}

Armstrong, Francis F. 'Manners and habits of the Aborigines of Western Australia', Perth Gazette and Western Australian Journal, 29 October, 5 November and 12 November 1836. (reprinted in Green 1979:186-206).

. 'Natives of... Oor-dal kalla commonly called Yalagonga's Tribe; ... '. CSR 1837. 58/158-164.

Backhouse, James. A narrative of a visit to the Australian colonies. London, 1843. [Reprinted New York, 1967.]

Baines, Pat. 'A litany for land', in I. Keen ed., Being black: Aboriginal cultures in 'settled' Australia, pp.227-249. Canberra, 1988.

Bates, Daisy. The passing of the Aborigines; a lifetime spent among the natives of Australia. London, 1938. [Reprinted Melbourne, 1966.]

The native tribes of Western Australia. Ed. Isobel White. Canberra, 1985.

Beck, Wendy, Anne Clark and Leslie Head. Plants in Australian archaeology. St Lucia, 1989.

Berndt, Ronald M. 'Aborigines of the south-west', in Ronald M. Berndt and Catherine H. Berndt eds., Aborigines of the west: their past and their present, pp.81-89. Nedlands, 1979.

Birdsall, Chris. 'All one family', in Ian Keen ed., Being black: Aboriginal cultures in settled Australia, pp.137-158. Canberra, 1988.

Bonnemains, Jacqueline. and P. Haugel (transcribers). Recit du voyage aux terres Australes par Pierre Bernard Milius, second sur le "Naturaliste" dans l'expedition Baudin (1800-1804). Museum d'Histoire Naturelle du Havre, 1987.

Bunbury, W. St. P. and W. P. Morrell eds. Early days in Western Australia being the letters and journal of Lieut. H.W. Bunbury. London, 1930.

Chauncy, Phillip Snell. 'Notes and anecdotes of the Aborigines of Australia', in R. Smyth, The Aborigines of Victoria and other parts of Australia and Tasmania, 2 vols. Melboume, 1878. [Reprinted Melbourne, 1972.]

CSR Colonial Secretary's Office Papers - correspondence received. Battye Library, Perth.

Drummond, James. 'Observations on the projected new line of road to Northam', Perth Gazette and Western Australian Journal, 28 May 1836.

Gibb, Martin. Aboriginal Gatherings in the West Coastal Region of Southwest Westem Australia: an ethnohistorical study. Honours Thesis, Centre for Prehistory, University of Western Australia, 1987.

Gott, Beth. 'Murnong - a Victorian staple food: some nutritional implications', Australian Aboriginal Studies 2, 1984: 2-17.

Green, Neville ed. Nyungar - the people: Aboriginal customs in the southwest of Australia. Perth, 1979.

Grey, [Sir] George. 'List of names of natives in Western Australia. By Lieut. Grey.' MS 523e in Sir George Grey's Library in the South African Library, Cape Town, 1838:

. Journals of two expeditions of discovery in north-west and western Australia, during the years 1837, 38 and $39 \ldots, 2$ vols. London, 1841.

Hallam, Sylvia J. Fire and hearth: a study of Aboriginal usage and European usurpation in south-western Australia. Canberra, 1975.

'A view from the other side of the western frontier: or 'I met a man who wasn't there .... Aboriginal History 7, 1983:134-156. 


\section{ABORIGINAL WOMEN AS PROVIDERS}

. 'The history of Aboriginal firing', in Julian R. Ford ed., Fire ecology and management of Western Australian ecosystems. Western Australian Institute of Technology Environmental Studies Group Report No. 14. Bentley, Western Australia, 1985:7-20.

. 'Yams, alluvium and villages on the west coastal plain', in Graeme K. Ward ed., Archaeology at ANZAAS Canberra. Canberra, 1986:116-132.

. 'Coastal does not equal littoral', Australian Archaeology 25, 1987a:10-29.

- 'Aboriginal resource usage along the Swan River' in Jacob John ed., Swan River Estuary: ecology and management . Curtin University Environmental Studies Group Report No.1. Bentley, Western Australia, 1987b:21-33.

. 'Plant usage and 'management in southwest Australian Aboriginal societies' in David R. Harris and Gordon C. Hillman eds., Foraging and farming: the evolution of plant exploitation, pp.136-151. London, 1989.

Hallam, Sylvia and Lois Tilbrook eds. Aborigines of the southwest region $1829-1840$. Nedlands, 1990.

Hammond, J. E. Winjan's people: the story of the South-West Australian Aborigines. Ed. Paul Hasluck. Perth, 1933.

. Western pioneers: the battle well fought. Ed. Oswald K. Battye. Perth, 1936.

Hookey, John. 'Settlement and sovereignty', in Peter Hanks and Bryan Keon-Cohen eds., Aborigines and the law: essays in memory of Elizabeth Eggleston, pp.1-18. Sydney, 1984.

Irwin, Frederick Chidley. The state and position of Western Australia, commonly called the Swan River Settlement. London, 1835.

Kennedy, James. 'Perth in my boyhood', Royal Western Australian Historical Society Journal 1, 1927:7-10.

Lyon, Robert Menli. 'A glance at the manners and language of the Aboriginal inhabitants of Western Australia', Perth Gazette and Western Australian Journal, 30 March, 6 April, 13 April and 20 April 1833. [Reprinted in Green 1979:148-180.]

Marchant, Leslie R. France ausirale: a study of French exploration and attempts to found a penal colony and strategic base in south western Australia 1503-1826. Perth, 1982.

Meagher, Sara J. 'Food resources of the Aborigines of the southwest of Western Australia', Records of the Western Australian Museum 3, 1974:13-65.

Meagher, Sara J. and W. D. L. Ride. 'Use of natural resources by the Aborigines of southwestern Australia', in Ronald M. and Catherine H. Berndt eds., Aborigines of the West: their past and present, pp.66-80. Nedlands, 1979.

Meehan, Betty. Shell bed to shell midden. Canberra, 1982.

Moore, George Fletcher. Diary of ten years eventful life of an early settler in Western Australia: a descriptive vocabulary of the language of the Aborigines. London, 1884. [Reprinted Nedlands, 1978.]

Pearce, R. H. and Mike Barbetti 'A 38,000-year-old site at Upper Swan, Western Australia', Archaeology in Oceania 16, 1981:173-8.

Peron, M. F. A Voyage of discovery to the Southern Ocean, performed by order of the Emperor Napoleon, during the years 1801, 1802, 1803 and 1804. (Translated from the French.) London, 1809. [Reprinted Melbourne, 1975.]

Reynolds, Henry. Aboriginal land rights in colonial Australia. (Occasional Lecture Series, No. 1, National Library of Australia). Canberra, 1988.

The law of the land. Ringwood, 1987.

Robert, Willem ed. The explorations, 1696-1697, of Australia by Willem de Vlamingh. Amsterdam, 1972.

Smith, Moya. 'Late Pleistocene zamia exploitation in southern Western Australia', Archaeology in Oceania 17, 1982:117-121.

Tilbrook, Lois. 'A question of access: women, marriage and land ownership in south-western Australia', Aboriginal History 10, 1986:99-116. 